\title{
Review of Discourse Components of Islamic Republic of Iran in the Middle East
}

\author{
Reza Abedi Gonabad ${ }^{1}$, Ebrahim Fayaz ${ }^{2} \&$ Ahmad Naderi $^{3}$ \\ ${ }^{1} \mathrm{PhD}$ students, Department of Cultural Policy Making, International University of Imam Reza, Mashhad, Iran \\ ${ }^{2}$ Assistant Professor, Department of Anthropology, Tehran University, Iran \\ ${ }^{3}$ Assistant Professor, Department of Anthropology, Faculty of Social Sciences, University of Tehran, Iran \\ Correspondence: Reza Abedi Gonabad, PhD students, Department of Cultural Policy Making, International \\ University of Imam Reza, Mashhad, Iran. E-mail: reza.aabedi@yahoo.com
}

Received: August 29, 2017

doi:10.5539/jpl.v10n5p105
Accepted: September 21, $2017 \quad$ Online Published: November 29, 2017

URL: https://doi.org/10.5539/jpl.v10n5p105

\begin{abstract}
With the victory of the Islamic Revolution, some shift in paradigm or the shift of discourse is observed in Iran. Islamic Republic System of Iran that was replaced instead of Pahlavi Regime took different discourse, behavior and function practically in addition to domestic policy at the level of foreign policy at the level of the Middle East or West of Asia and North of Africa and this approach was definitely different from the past. The discourse had a central indication of jurisprudential political Islam as the social and political protest against national Iranian radical otherness, western quasi-modernism, secularism and militarism of Pahlavism Discourse, which was created by the friction and dialectic between dominant discourses of similarity to west and discourses different from the west. In this study, 4 components and indices of anti-arrogance Islamism, monist Shiism (establishment of the Islamic Ummah), independence and anti-order orientation based on supporting Axis of Resistance against Axis of Compromise are explained as discourse components of the Islamic Republic of Iran in the Middle East. The data analysis method in this study is mainly based on qualitative methods. Moreover, this study has used data description and analysis using documentary references and methods and through referring to the library and internet.
\end{abstract}

Keywords: discourse, Islamic Republic of Iran, Middle East, anti-arrogance Islamism, monism Shiism, independence, anti-order orientation based on supporting Axis of Resistance against Axis of Compromise

\section{Introduction}

Revolution of the Islamic Republic of Iran as a big revolution is one of the most important and greatest historical evolutions in the second half of the 20th century. This movement happened in the peak of military and economic power of Pahlavi dynasty; although the imagination of such event surprised not only superpowers, but also some revolutionists and a revolution not in the type of violence, but cultural revolution and in short, cultural soft revolution (Izadi and Mohammadi, summer, 2011: 7). West and America were confused against the revolution deeply and such confusion provided conditions for Iran's Revolution to consider the creation of alternative discourse based on novel political Islam in its agenda (Me'badi and Khodaverdi, 2006: 15). After the victory of the Islamic Revolution and change in the domestic and foreign attitude of the Islamic Republic of Iran in the West of Asia and North of Africa and separation from West power block and taking the opposite position, the type of relationship and behavior of neighbor countries with the Islamic Republic of Iran was completely changed.

Some regional countries took a position against Iran instead of being aligned and fight against trans-regional states. The cultural and soft nature of the Islamic Revolution and fear of release of waves of Bahman 1979 Revolution could arouse the concern of many Arab Leaders. From the perspective of these governments, Islamic values and norms with Islamic Republic discourse called as an Islamic ideology with Shiite perceptions was introduced risky. In other words, Islamic Revolution was important in 5 dimensions, including the revival of religious identity; ideas of Islamic rule; defend the ideals of the Palestinian people in the world; considering unity and Islamic solidarity against the West and finally, presenting the discourse in the Middle East. In this meaning, the Islamic Republic and its cultural diplomacy based on independence, justice, rejection of 
domination and improve the movement of liberation was considered as a new activist in the international and regional system. After the attack of Iraq to Iran that was a reaction of discourse of competitor to maintain the existing position against Islamic Revolution discourse and Islamic Republic and the collapse of Saddam Hussein in 2003; Lebanon 33 War, multiple wars of Israel against the besieged people of Gaza and Islamic Awakening Movement; regional power of Iran was presented openly in frame of Islamic Republic Discourse.

Discourse of Islamic Republic of Iran in the Middle East is very important due to importance of this zone in world equations in dimensions of geopolitics, geostrategic and geo-culture dimensions and location of the Middle East and its subsystems in the defending domain of Islamic Republic of Iran because of common borders and historical and cultural backgrounds as long as pre-Islam history and efforts of this country to be changed into first regional power in senior documents such as 2025 Horizon Outlook. Hence, this study has used theory of discourse analysis and after analyzing the Discourse of Islamic Revolution and the Islamic Republic of Iran with central indication of jurisprudential political Islam and Pahlavi discourse in West of Asia and North of Africa called by western associations as unreal and imposed and based on colonial functions of the Middle East, the authors tend to answer the question that what indices and components dose include the regional discourse of the Islamic Republic of Iran?

\section{Definition of Concepts}

\subsection{Discourse}

The term "discourse" has been applied in different, but close meanings over the time and by scholars in different fields (Yarmohammadi, 2012: 1). Foucault believes that discourse refers to a series of sentences till the time that is belonged to common discourse formation. Discourse is formed of the limited number of sentences, for which some existential conditions could be defined (Foucault, 1989: 117). The attitude of Fairclough is as follows: discourse refers to use of language as social affairs (Fairclough, 1995: 7). Van Dyke has also defined discourse as follows: "discourse is at the same time special form of use of language and a special form of social interaction; discourse is an absolute relational event in a social situation" (Rahiminia, 2014: 116). Laclau and Mouffe in the book "Hegemony and Socialist Strategy" (1985) have defined discourse as meaningful series of linguistics and meta-linguistics signs and signifiers. In fact, they consider discourse as a structured generality gained by detailed action (Laclau and Mouffe, 1985: 193). Discourse can make meanings and social relations and can form subjectivity, political relations and also power relations. Each kind of activity leading to exchange of meanings in the frame of cultural interactions is a kind of discourse. Discourse is a concept that is used implicitly by Antonio Gramsci and is also applied by Michel Foucault, social philosopher, (1926-1984) explicitly (Motaharnia, 2003: 27).

\subsection{Islamic Republic of Iran}

The Islamic Republic is the form of government, which was dominated by Iran after the Islamic Revolution. Since the time of the presence of Imam in Paris, the Islamic Republic regime was always reminded as a desirable regime by him (HusseiniZadeh, 2007: 284). The term "Islamic Republic" is a combination of two words of "republic" and "Islam". The republic is derived from a Latin origin "Republica" and in Persian; it means all people, group, large population, large and dense. According to Constitution of the Islamic Republic of Iran, the principle of Islamic Republic government is on basis of Republican and Islamism. Republican is same votes of ordinary people to run state affairs and Islamism means adjustment of regulations with the Islam religion. In the Islamic Republic of Iran, Republican refers to the model of the government and Islamism is an indicator referring to its content. Imam Khomeini believed that Islam encompasses many democratic indicators like freedom, equality, independence and other indices. Hence, he has rejected suggestions of some political groups based on Islamic democratic republic and has emphasized the Islamic Republic exactly. From the perspective of Imam Khomeini, the difference of republic in Iran with other republics is cleared with the term "Islamic". The indicators of the Islamic Republic of Iran could be identified in 3 arenas: first in field of belief that could be completed with political philosophy; second in structure arena and third in field of behavior, for which jurisprudence and other Islamic sciences are responsible to clear their dimensions. In the Islamic Republic of Iran, the 3 indices are originated in Islamic thought (Noruzi, 2010, 32-35). The nature of sovereignty in the Islamic Republic of Iran is divine, national and democratic nature. Velayat-e Faqih is the basis and foundation of the Islamic Republic of Iran.

\section{Discourse Components of Iran in the Middle East before Islamic Revolution (Pahlavi Era)}

In short, the important components or indices of regional discourse of Iran before the victory of the Islamic Revolution (Pahlavi Era) in the field of foreign policy are as follows: 


\subsection{First: Regional Dominance and Transregional Dependence Discourse}

Dynamicity of decision making and implementation of Iran foreign policy in last 15 years of Pahlavi Regime has spent a process that was mostly affected by international system and the USA as the main actor of this system compared to other domestic and foreign factors. Following world policy of the America increased hand-puppet role of Iran government and could also decrease the effectiveness of national elements and dynamicity of foreign policy decisions (Arghandi, 2013: 447-448).

In regional dominance discourse, empowerment of hardware powers, regional military preference, negligence of regional beliefs; e.g. supporting Israel, social and identical separation from other regional societies on one hand and in transregional dependence discourse, in overdependence on America, attempting to cope with the Europe and even under relative contrasting conditions with national interests, political and economic consistency with Israel to gain superpowers have been the most important elements forming Pahlavi Era discourse in relation to the Middle East.

\subsection{Second: Racial Superiority and Historical Identity Discourse}

The discourse is rooted in Arian racial superiority to other regional races on one hand and Iran's royal civilization as the historical identity on the other hand. During the mentioned period, it has been tried to impose the said identity on the society to an extent that it was not seriously in conflict with Islamic religious thoughts and principles. Holding Shiraz 2500-year celebrations and change in solar calendar to Royal Calendar have been just two examples of the said discourse in operational level and representation of past times in contemporary thinking, cultural and social through of Iranians. Magnifying this racial superiority and historical identity can reflect its message compared to races and regional history.

\subsection{Third: Regional Leadership and Persian Empire Revival Discourse}

Applied foreign policies of Iran had identity support, so that the efforts of Iran were directed to increase national power and changing to regional hegemony with the aim of showing preference of Iranians on Arabs and continuity in the position of an ancient culture and cultural pride (Mousavizadeh and Javedani Moghaddam, 2008: 218). The said discourse, with linking to states like America, Israel, South Africa (at the time of apartheid) was trying to revive the Persian Empire based on the royal power on one hand and modernity of secular on the other hand. Achieving to lost glory and revival of constantly present past and nation-orientation (Mostaghimi, 2007: 112-117) based on past Empire History have been the most important elements feeding this discourse.

\section{Iran's Regional Discourse after Islamic Revolution}

Iran's foreign policy in pre and post-revolution time has been affected by such considerable differences, which can be called as a shift and a passage in paradigm (Rezaei Panah and Nematollahi, 2015: 120). This issue is affected by the nature of Islamic Revolution Discourse as an idealistic, Islamist and universal revolution, which has its origin in Islamic Religion and has been created by a unique and wise leader in the Islamic World (Javedani Moghadam, 2009: 62). The slogan "Neither East, Nor West" was changed into appearance of a certain foreign policy pattern, which could be considered as the translation of political changes and evolutions and the goals and ideals created by the Islamic Revolution in international level. After the victory of the Islamic Revolution, Islamic Republic of Iran and the discourse created by it from transnational dimensions; has targeted the Middle East or East of Asia and the Islamic Republic Perspective Document in Horizon of 2025 clearly refers to efforts of the Islamic Republic for inspiration and changing into first regional power with regard to Islamic considerations. This region is based on superior documents of the sphere of influence and the main maneuver of Iran's foreign policy; such region that includes several interconnected and even independent geographical districts. The Islamic Republic of Iran, which has been identified as a quasi-isolated country, according to some analysts in regional affairs, has been changed into one of the main actors in the frame of the Middle East. Some scholars in the field of International Relations believe that Iran has the potential ability to become the superpower state in the Middle East. For example, Barry Rubin believes that Iran is the only power in the east of Asia and North Africa and says: "no Arab state can claim for such power" (Tooti and Doostmohammadi, 2013: 121). In the rest of paper, through considering the presumptions, it has been tried to determine the most important indicators and components considered by Middle East Discourse of the Islamic Republic of Iran.

5. The Most Important Indicators and Components Considered by Islamic Republic of Iran Discourse in the Middle East

\subsection{Anti-arrogance Islamism}

After the victory of the Islamic Revolution, the main element conducting Iran's behavior of foreign policy can be 
Islamic norm and value called as Islamic ideology (Javadi Arjomand and Chaboki, 2010: 45). Therefore, when talking about Islamic Republic, at the first the adjective "Islamic" can determine a series of norms and values, creating a kind of Islamic Identity for this country. This Islamic identity is not secular and is on the basis of political Islam. The identity of Iran Revolution, in addition to domestic political-social evolutions, has paved the way for crystallization of new discourse and wide effects in regional level (Javedani Moghaddam, 2009: 68). Accordingly, the main element conducting Iran's behavior of foreign policy can be Islamic norm and value called as Islamic ideology. In this framework, one of the identity aspects inserted in Islamic Revolution discourse is protest to dominance of strangers and foreigners and fighting arrogance (Ashraf Nazari, 2012: 61). From this perspective, with regard to Islamic and Quranic concepts, dividing the universe into two parts of arrogant and oppressed is emphasized.

In lexical definition, arrogance means magnifying something or someone, self-grandiosity and pride. Arrogance is the practical state of pride, along with insubordination and rebellion. The pride and rebellion are clear in personal acts and can humiliate others and can be appeared in the affairs of others as decision maker (Ehsani, 2001: 20). In Quran culture, arrogance refers to a social system with false grandiosity and superiority and with a tendency to have cruel and oppressive dominance on the society (Safavi, 1992: 13). The term "arrogance" and its derivatives are used 56 times in Holy Quran and this can reveal the importance of it and deep concepts with this term.

From an Islamic perspective, the concept of oppression and arrogance refers to the existence of a kind of dominance and colony and cultural and political and economic abuse by a cruel minority on a wide range of deprived people (Dehghani Firrozabadi and vahabpoor, 2013: 75). From an Islamic and Quran perspective, the natural and antagonistic contrast of arrogance and oppressed people is observed. Arrogance is a feature of atheism and hence, the worldwide atheism system is known as arrogance (Ehsani, 2001: 73-74). The most important features of arrogance are as follows:

1) Self-righteousness

2) Truth rejection

3) Permitting crimes against humanity

4) Deceit and hypocritical behavior (Ghorbani, 2016: 149-150)

Islamic revolution has such identity that is in conflict with the interests and goals of domineering people and tyrants. Hence, due to revolution leaders, the pioneers of atheism and arrogance never tolerate advent of Islamic Revolution in domain of East of Asia and in international level and fight against it with their best instruments and facilities and never end these destructive measures till the collapse or change the main nature and identity. This attitude is the most dominant attitude of Iran's foreign policy making and has been reproduced with the repetition of hostile accidents and disputes of this age (Dehghani Firrozabadi and Vahabpoor, 2013: 76-77).

Fighting arrogance in the regional discourse of Islamic Republic is also affected by Rule of Denial of Dominance is formed as the revisionist rule of the Islamic revolution, which has rejected current international structures and norms and has emphasized the necessity of freedom of any kind of dominance and dependence (Khosroshiri, 2009: 82). The verse "and never will Allah give the disbelievers over the believers a way [to overcome them]" that is known as Naf'I sabil Verse and emphasizes a preference of believers on disbelievers or fighting against the dominance of disbelievers on believers, is one of the most important indicators of Islamic ideology. According to this verse, denial of the dominance of strangers or fighting against the domineering system is the first priority of the Islamic Foreign Policy. In addition to Islam, belief in an old fight between good and evil and light and darkness is rooted in depth of Iranian culture and dates back to ancient times. The continuous fight between good and evil and light and darkness makes people for positioning and under such conditions, passiveness is criticized. Fighting arrogance can be the interaction point of Islamism, Iran-orientation, Third World-orientation and revolutionism (Dehghani Firoozabadi and Vahabpoor, 2013: 75).

The issue of protecting oppressed people against arrogant people of the world for the Islamic Republic system was significant to an extent that the founder of the Islamic Republic, Imam Khomeini (PBUH), presented the idea and project of establishment of a world party called "The Oppressed Party" several months after the deployment of the Islamic Republic System in Iran (Musavi Khomeini, 2007: 140; Safavi Homami, 2008: 112). The concept that the Islamic revolution architects found is the division of the universe into oppressed and arrogant parts. Hence, when the countries of the world are divided into two domains of arrogance and oppression, macro strategy in this attitude is as follows: the first strategy is protecting the oppressed of the world and this strategy is explained clearly in reliable documents such as Iran's Constitution. Another strategy is fighting 
against domineering people till the time of establishment of global justice by Imam Zaman (Behrooz Lak and Hamedani, 2014: 10). Imam Khomeini believed that opries of oppressed people could be the only way for their adjudication.

This concept in the regional domain and international relations after that Imam Khomeini passed away is "anti-arrogance" for Ayatollah Khamenei. In this discourse collection, arrogance means "supremacy" created sometimes by individual, group or a society towards other poor individuals, groups and societies that are the same overcoming and dominating on others. Ayatollah Ali Khamenei has mentioned 3 features for arrogant systems: "self-supremacy, truth rejection, humiliation and assault to social classes and deception". Hence, in addition, to opposing to these triple features, Islamic System fights against arrogance systems. In this framework, ideas, events and processes in conflict with the anti-arrogance approach in the field of foreign policy are criticized (Ajili et al, 2014: 115-116). The principle of fighting against arrogance has been also reflected in the Constitution of the Islamic Republic of Iran. Certainly, the articles 152 and 154 have reflected it directly. The Islamic Republic of Iran has used and spread the anti-arrogance Islamism and has become responsible for global leadership of fighting against arrogance and oppression in West of Asia and has tried to protect Islamic and liberalist movements in its foreign policy important manifestation of this issue is observable in the issue of Arabs and Israel. The intention of Islamic Republic by considering supporting oppressed people against arrogant people in field of regional and global discourse components is not to be replaced instead of superpowers and world arrogance trough collapsing them and act in same way, but also it tends to fight against arrogance ta the world and such a value and culture-based fight to remove the pressures and obstacles against human evolution and living freely and thinking freely and choosing the best way of living (Safavi Homami, 2008: 112). Accordingly, Islamic Republic of Iran believes that the Zionist regime of America as the current symbol of colonial values and tendencies of West and rejects any kind of compromise with it.

\subsection{Monist Shiism: Establishment of Islamic Ummah (Nation)}

Shiism is an unavoidable part of Iranian identity and the source for political legitimacy since the 16th century; the time that the first religious government has emerged in Iran. Shiite Islam was mixed with the policy from the beginning (Esposito, 2014: 33). However, it seems that in a historical consideration, during 1941-1979, political and social revolution has been established in political thoughts of Shiite and an age with prosperity of religion-based movements in Iran is observed. Evolutions such as paying attention to social and political issues from a religious point of view, equipping and rethinking about concepts such as jihad, martyrdom, Taghiye, tolerance, review of the affairs of the clerical establishment and authority and preparing it for new evolutions could provide the conditions for a proving theory on government or political system with emphasizing religious self-awareness at the contemporary world and the necessity of revise of the relationship between religion and politics (Derakhsheh, 2005: 5-6). The new political discourse of Shiite, after the victory of the Islamic Revolution, has been able to use Jihad to find answers to the most important fundamental challenges caused by continuing the process of contradiction of "tradition and modernity" at the Iranian society. Also, it has been able to provide the conditions for understanding modern political institutes and concepts to pass the stage of imitating imported models and enter to the establishment step that is related to localization and theorizing based on original Islamic references; an issue that is interpreted as "excellence" of Shiite political discourse. Through using Shiite deepening strategy, Islamic Republic of Iran has been able to expand its strategic depth.

However, from the perspective of Arab states and mainly Sunni states in West of Asia, the Islamic republic of Iran and its jurisprudential and shiism attitude was considered as a threat. In this perception, it was imagined that Islamic Republic tended to export the Velayat-e faqih pattern and promote Shiite religion among Sunni Arabs around the country. However, it should be noted that firstly, neither Sunni nations have the ability to make Iranian Shiite people become Sunni nor the Shiite Iran can promote Shiite religion among majority of Sunni states. Secondly, despite the perceptions and imaginations of Sunni states and Western Media, the Discourse of the Islamic Republic of Iran in West of Asia has monism attitude. The Islamic Republic believes in civilization in the form of new Islamic civilization. Hence, the new Islamic Civilization is impossible without the participation of the majority of Sunnis. This attitude is despite to the worldview of Wahhabi discourse and radicalism of Shiite religion called by Ayatollah Khamenei as English and London Shiite. This monism perception has its origin in the Shiism considered by theorists and leaders of Islamic Republic.

It should be noted that Islam has considered worldwide mission for people and has targeted all racial and tribal identities, relative and family relations. Holy Quran says: "Indeed this, your religion, is one religion, and I am your Lord, so worship Me". The emphasis of Quran on unity and monotheism is not limited to inviting people to unify religion and worshiping the Almighty Go, but also Muslims as a part of this unit nation have been invited for internal unity and integration. Nationalism orientation could be also observed properly in the life of Prophet 
Mohammad and Shiite Imams. Islamic unity means choosing one and only religion and leaving other religions or new religious inventions through taking common points and rejecting everything else. Islamic unity refers to the cooperation of followers of Islamic religions based on common principles of Islam and taking unit positions to realize excellent goals and interests of the Islamic Nation and unit positioning against enemies and respecting practical and spiritual requirements of Muslims to their own religion (Parsa, 2008: 249). According to these notes, one of the most important identity norms of the Islamic Republic of Iran system created by the Islamic-religious culture is attempting in way of unity of Islamic nation and making unit Islamic government across the world.

The founder of Islamic Revolution believed that lack of unity is against the interests of Shiite and Sunni. From this perspective, interests of all Islamic countries were interrelated. Imam Khomeini believed that those making disputes among Muslims are neither Shiite nor Sunni. From this viewpoint, they are people who want to make enemies of Islam overcome Muslims (Musavi Khomeini, 2006: 594-595). Interestingly, although Imam Khomeini was a Shiite Marja and believed in basis of Shiite religion, he never emphasized Shiite revolution and republic in his official or even nonofficial literature. Support of Islamic Republic for Sunni liberal movements in the early days of victory of Islamic Revolution could be another document of the Iran unit nation after the revolution. For example, after the victory of Islamic Revolution in Bahman 1979, the highest range of financial, military and political aids of Iran was provided for Palestinian Resistance Groups. After that Imam Khomeini passed away, unity-based attitude continued in worldview, words and behavior of Ayatollah Khamenei as a Shiite jurist in response to regional evolutions and conducting Middle East discourse in this country.

The explicit opposition of Ayatollah Khamenei with any kind of divisive measure of parties and Shiite and Sunni claimants can be a sign of attention of the peak of the pyramid of the Islamic Republic to the issue of unity. The reflection of identity norm, attempting for Islamic unity and unit Islamic government in the Constitution of the Islamic Republic of Iran could be considered as the most important legal order dominated in this country. Article 11 of Constitution says: In accordance with the sacred verse of the Qur'an ("This your community is a single community, and I am your Lord, so worship Me" [21:92]), all Muslims form a single nation, and the government of the Islamic Republic of Iran has the duty of formulating its general policies with a view to cultivating the friendship and unity of all Muslim peoples, and it must constantly strive to bring about the political, economic, and cultural unity of the Islamic world (Constitution of Islamic Republic of Iran, 2003: 52). In addition to this article, the Constitution has mentioned in its introduction that, having regard to the Islamic contents of the Iranian Revolution, the government has to provide the conditions for continuity of the revolution in abroad and especially in field of expanding relations with other Islamic movements to establish unit Islamic nation. It should be noted that Iran wants to have the most regional influence and this can be realized when the Islamic Republic of Iran is not a sect actor (Khezri et al, 2015: 197).

\subsection{Independence}

This term has been considered in terminologies and has been translated as "separation of authority and sovereignty of a country from other countries (other authority)" in political dictionaries (Harsij, 2010: 131). Independence is a collection of self-reliance, self-sufficiency and needlessness and capabilities. Independence means reliance on self and no dependence on any other person. At this point of view, independence means lack of interference of other stranger authorities in state affairs and independence of state performance against foreign authorities. Hence, independence refers to having decision making power and policy making power, along with use of these decisions and policies in domain of sovereignty (Taghizadeh Ansari, 2000: 90).

Independence has 3 political, cultural and economic aspects. The Individual or the society and nation seeking independence tend to minimize and decline dependence and reliance on strangers. Independence has two aspects: foreign independence that refers to freedom of action in communicating other countries and foreign issues and domestic independence that refers to freedom of action in the framework of state limits. Independence is a legal concept meaning the use of sovereignty of a government to limit of geographical borders and defending these borders against assaults and interferences of foreign countries. The concept of independence in foreign relations of a government with other government is used when a state can defend its goals and national security and interests and in foreign policy. The independence includes independence in 3 steps of policy making, decision making and implementing the policies and decisions and the examples of these steps have appeared in political, economic, cultural and defensive fields (Sotudeh, 2014: 44).

From the Islamic point of view, the dignity of Islam has appeared in economic, political, military, cultural and thinking independence against abjection that could be appeared in all said fields (Husseini Tehrani, 2014: 87). Unique geographical location and geopolitical position of Iran has made this country to be considered as an 
important state by other countries and international powers over the history and be threatened and interfered and assaulted by them. Such subjectivity of the existence of external element has led to the creation of a kind of sense of independence seeking among the Iranian people and their political culture. Therefore, the sensitivity of Iranians to the independence of their country is originated in their deep and detailed feelings about their political culture.

The advent of Islamic Revolution in Iran with independence seeking has played a vital role and has been also considered as one of the main goals of the revolution. To confirm this perception of Islamic Revolution, one can refer to the analysis of Ruhollah Ramezani in this field: at the same time that advent of Islamic Revolution in Iran on 1979 could shoe opposition of Iran nation to domestic policies of Shah; it could refer to dissatisfaction by his foreign policy too. This is because; the axis of attacks of opponents of the Shah to his foreign policy was formed by criticism of his practical unity with the USA and hence, he was labeled as American Shah (Ramezani, 2007: 46).

Independence seeking was changed into the main axis for revolutionary slogans emphasizing cut of dependence on Western powers and comprehensive independence of Iran (Sotudeh, 2014: 44). Accordingly, later and with the establishment of Islamic Republic of Iran and the operational dimension, independence in decision making in domestic level and protecting territorial integrity and independence from the trans-regional powers and opposition to their presence in the zone of West Asia can be considered as examples of the Independence-based tendency in foreign policy and regional discourse of Islamic Republic. In the Islamic Republic Discourse in West Asia, presence of forces and heavy equipment of countries like America weakened the security and independence of Iran and Arab states and also a factor to intensify the gap and dependence of countries on the West.

Reduction of reliance and dependence on the US and taking more independent policies of regional states could result in the reduction of threats to Iran and the empowerment of the position of this country. Also, if the dependence of these countries on America is increased, the risk, obstacles and threats would be increased for all goals and indicators of the discourse of Islamic Republic of Iran in West Asia. If the concept "sweeping balance" in international relations is generally considered as a policy made by large states and main regional actors; which have acted at least with no reliance on the trans-regional powers against the threats of the surrounding area, the independence components of independence of discourse of Islamic Republic in West Asia and North Africa could be analyzed in this framework. However, the concept of independence in the Middle East discourse of Islamic Republic doesn't mean isolationism.

\subsection{Anti-Order Orientation Based on Supporting Axis of Resistance against Axis of Compromise}

In the structure of regional order before 1979, Iran was considered as a ring of extended defensive chain against the influence of communist by the west, which was responsible for linking the NATO Treaty to SEATO Treaty. In the framework of order making and anti-Soviet strategies of the USA, Iran was an important element because of maintaining the stream of oil export and providing Israel Security (Ghazanfari, 2001: 109). Iran was the protector of order considered by West and America and used also to express its opposition with any kind of communist movement and even liberals and resistance movements.

From the beginning of revolutionary evolutions in Iran, international important actors who used to conduct interest and regional order in the region, especially America and Former Soviet as two superpowers of that years expressed their concern about the situation. It should be noted that the role of revolutionary government could affect hegemonic order theories. The existence of this government was caused by the impossibility of denial of the dispute and inequality in different domains of the world (Griffiths, 1999). The revolutionary government in these theories is the government that searches collapse of this system through imposing fundamental criticisms on fundamental principles of the current system and takes hostile actions against other countries in this way intentionally and based on an internal revolution (Armstrong, 1993).

Advent of Islamic Revolution of Iran and revolutionary slogans based on rejection of capitalization and the socialist system and protection of liberal movements at the Third World and the Islamic World could provide the conditions for the disputes between Iran and superpowers. In this field, the government of the Islamic Republic of Iran defines the orientation of its foreign policy and basis of its interactions with the outside world based on various Quran verses and the Rule of Denial of Dominance. After revolution, Iran as a revolutionary country announced the policy of "neither east, nor west" and the anti-order and revisionist approach and brought a new wave of deformations in the field of international relations and the West Asian and North African space.

After Islamic Revolution, Iran presented some values and norms, which were conflicting with the interests of powers supporting the current status. Some of these values are as follows: independence, freedom, justice, right 
to self-determination, unity and alliance of the poor, the awakening of Muslims, the rightfulness of deprived nations, right seeking and cooperation and fight against authoritarianism, ravages, extortion, possessiveness, aggression, imperialism, colonialism, ignorance and division. Iran tried to affect the public opinions of deprived and poor nations of the third world through these values to change the international system. In view of the supporters of current status, imposing war against the Islamic Republic of Iran was a big obstacle against realization of this revisionist view and could involve an Iran fight for 8 continuous years against Iraq. Moreover, establishment of the Persian Gulf Cooperation Council was to strength the regional security against anti-order nature of Middle East discourse of Iran.

Hence, it could be mentioned that the Islamic Revolution by itself has anti-order nature in the international environment and the West Asian region. Moreover, the system behavior created by it in the international and regional level could be called as anti-hegemony based on natural conflict. However, the anti-hegemony has gone beyond the limits of the definitions and Iran tends to destroy what is called as imported hegemonic order and imposed hegemonic order by domineering powers with the West orientation. Hence, Iran is not only tended to oppose other states and present revisionist ideas, but also Iran believes that it should interfere in regional and international space actively and destroy the order desired with trans-regional powers and their allies among Middle East states and create new order based on desired values of Iran.

Hence, the term anti-order could be used to explain components of Middle East discourse of the Islamic Republic of Iran. According to these explanations, the anti-order orientation is based on protecting an orientation named "Axis of Resistance" against "Axis of Compromise". The component of the Middle East discourse of the Islamic Republic is itself formed of 3 components of anti-arrogance Islamism, unitary Shiism and independence explained before. In other words, it should be mentioned that the 3 components could be typically anti-order nature of superpowers and challenging them.

According to Christopher Kalafut" and "Suu Kyi", Iran Revolution has resistance approach similar to other revolutions of the third world on one hand and has been tended to consider resistance power as identification leverage on the other hand. After the collapse of Iran's bipolar order in the new unipolar order leading by the USA, the dimensions of the changes were not accepted completely and this led at the same time to increase in pressures on Iran. Shirin Haunter the invited processor of "Iran's Foreign Policy in the Post-Soviet Era: Resisting the New International" believes that Iran's foreign policy in post-soviet age lacked independence-based aspect because of special indicators dominated on the nature of the political system and its ideals. Hence, it has changed resistance against the existing order into its macro strategy with paying for it (Haunter, 2010). The orientation of Iran Revolution ideology is not only challenging for the strategic goals of superpowers, but also it has some effects of criticism of regional policies of efficiency and structural legitimacy of regional conservative branches (Pustinchi, 2010: 17-19). Now, it should be found that what is the meaning of the Axis of Resistance in Middle East Discourse of Iran after the revolution? Before answering the question, it should be noted that the Axis of Resistance called as Axis of Resistance discourse by some scholars gains meaning and identity versus the Axis of Compromise or discourse.

To explain these concepts, it could be mentioned that West of Asia is divided to two axes of compromise and resistance almost in all fields. The system of the Islamic Republic of Iran as a focal country, in alliance with Syria, Lebanon Hezbollah and Hamas movement and Islamic Jihad form this axis. In opposite point in the Axis of Compromise, south rim of the Persian Gulf Arab States, Jordan and Egypt were present with the alliance of America. Saudi Arabia and Egypt were the cores of power in Axis of Compromise (Niyakuyi and Sotudeh, 2015: 100). The Axis of Compromise in West of Asia is identified sometimes under the titles of "Axis of moderation", "conservative" and "Arab reaction". The difference of the attitude of the two mentioned axes of compromise and resistance towards regional issues could be mostly observed in following items:

1) Looking at the Question of Palestine: The Axis of Resistance believes that the solution of the question of Palestine is resistance against the occupiers and also believes that the only fair way to solve the crisis is public resistance and referendum of the owners of Palestinian lands. On the contrary, the compromiser conservative axis believes that this crisis must be met using diplomatic methods. In general, the Axis of Compromise, especially Saudi Arabia, have always been tended to solve their disputes with the Israel.

2) Looking at the West: From the perspective of the Axis of Resistance, Western states, especially the United State, have a destructive role in the zone and some policies of these countries in West of Asia can be the reason for the major part of the problem in this zone. Moreover, Axis of Resistance criticizes Western countries because of their supports for the Zionist Regime. On the contrary, although the conservative axis sometimes criticizes the Western States, especially America, because of supporting Israel, it believes in separation of issues and 
cooperates with Western countries in different fields. In other words, this stream doesn't believe that some disputes in some fields with the Western states are obstacles against the cooperation in other domains and have positive and optimism approach to the West and especially America.

3) The foreign policy: To the extent that is related to West of Asia, the conservative axis has a conservative approach to the world and regional order and has no tendency for rapid and deep changes. In other words, it follows the policy of maintaining the existing status. However, Axis of Resistance believes that the relations in world level generally and in regional level specially are not fair and in fact, this axis follows a revolutionary policy. In fact, Axis of Resistance has revisionist policy (Babaei, 2015: 92-94).

This axis were established after the attacks of America and its allies to Afghanistan and Iraq at the beginning of the first decade of the second millennium and was a reaction to these attacks. Opposition with foreign interferences and formation of endogenous security system could be two important principles of the Axis of Resistance. This axis could be typically considered as an effect of the presence of power and influence of the Islamic Republic of Iran in the zone. In fact, the logic of this axis could be considered as a feedback of Iran's attitude towards regional issues after Islamic Revolution (Khajuei, 2015).

Axis of Resistance as the only serious opponent of presence of America at the Middle East took some policies and measures like opposition to Zionist Regime, opposition to Arabic conservation and decayed form of its government, opposition to presence of America at the region, belief in oil as an instrument to impose pressure on West, supporting Palestine ideals, acceptance of forgotten role of people (democracy) in self-determination, rise and empowerment of Shiite minorities in alternative democracies and revival of religion-oriented thoughts and Islamic movements' growth in the frame of promotion of Islamic Awakening in public opinions of the regional people to increase costs and decrease interests of America in the region (Parsai and Motaharnia, 2014: 107). Something that gives soft power and discourse power to the Islamic Republic of Iran (advantage of the Islamic Republic of Iran in the current order) is a resistance and fight against the world oppressors (Adami and Keshavarz Moghaddam, 2015: 1).

\section{Conclusion}

The discourse of the Islamic Republic of Iran with central indication of Islam should be considered as social and political protest against national Iranian radical otherness, western quasi-modernism, secularism and militarism of Pahlavism Discourse, which was created by the friction and the dialectic between dominant discourses of similarity to west and discourses different from the west. The Middle East discourse of the Islamic Republic of Iran includes 4 indicators, including anti-arrogance Islamism, monist Shiism (establishment of the Islamic Ummah), independence and anti-order orientation based on supporting Axis of Resistance against Axis of Compromise. The elements of anti-arrogance Islamism, monist Shiism (establishment of the Islamic Ummah), independence and anti-order orientation based on supporting Axis of Resistance against Axis of Compromise have some overlaps with each other in some cases. The indices are derived from dimensions of Islam Religion, Shiite Religion, Ancient Iran and Contemporary Iran History, guidelines of Islamic Revolution Leaders such as Ayatollah Khomeini and Ayatollah Khamenei and Constitution of the Islamic Republic of Iran and other reliable documents.

It should be noted that the components of the regional discourse of the Islamic Republic of Iran are significantly different from the previous regime. In Pahlavi Era, Iran was seeking domination at the Middle East, especially under Persian Gulf System. In this sense, however, the dominance could be meaningful with the dependence on the West and defending interests of capitalization block against communism block, fighting against factors destructing the existing order, relations with Israel and other allies of the US and providing energy security. Regional discourse of Iran at Pahlavi Era used to follow racial superiority and historical identity. Iran was seeking regional leadership and revival of Iran Empire in West Asia and North Africa. Islamic Republic of Iran and the desired discourse by the state with the mentioned indices under current conditions and in a long-term horizon tend to achieve novel Islamic Civilization and formation of the Islamic Middle East against Anglo-American order and structure imposed on these geographical areas and to change the Islamic Republic of Iran into the first regional power and move towards hegemony of Islamic Revolution Discourse.

\section{References}

Adami, A., \& Keshavarz Moghaddam, E. (2015). the security of the axis of resistance in foreign policy of the Islamic Republic of Iran. Journal of Political Studies of the Islamic world, 4(14), 1-19.

Ajili, H. et al. (2014). Discourse analysis, Ayatollah Ali Khamenei, Iran's relations with the United States of America. Islamic Revolution Research, 3(9), 109-134. 
Arghandi, A. (2013). Iran's foreign relations (hand-puppet government) in 1941-1979. Tehran: Ghomes.

Armstrong, D. (1993). Relation and world order. Oxford: Clarendon press. https://doi.org/10.1093/0198275285.001.0001

Ashraf Nazari, A. (2012). Religious innovation and excellence in the political discourse of Imam Khomeini. Journal of the Islamic Revolution, 1(3), 55-78.

Babaei, P. (2015). Cause of trend for the axis of resistance in Yemen. Journal of Strategic Studies of the Islamic world, 16(62), 85-108.

Behrooz lak, Gh. R., \& Hamadani, M. A. (2014). America's relationship with Shiite political jurisprudence revolving around the ideas of Imam Khomeini. Journal of the Islamic Revolution, 3(10), 7-34.

Constitution of the Islamic Republic of Iran. (2003). Tehran: Advertising and Publishing Department of the Islamic Consultative Assembly.

Dehghani Firoozabadi, J., \& Vahabpour, P. (2013). Ontological security in foreign policy of Islamic Republic of Iran. Tehran: Institute for Strategic Studies.

Derakhsheh, J. (2005). Shia political discourse in contemporary Iran. Tehran: University of Imam Sadeq (AS).

Ehsani, Y. (2001). Arrogance. Tehran: Zohd Cultural Publications Institute.

Esposito, J. L. (2014). Iranian revolution and the global impact of it. Trans: M Modir Shanehchi n. Tehran: Reconstruction Center of Islam and Iran.

Fairclough, N. (1995). Critical discourse analysis: the critical study language. London and New York: routledge.

Foucault, M. (1989). The Archaeology of Knowledge, Translated by A. Sheridan, London: Routledge.

Ghazanfari, K. (2001) America and overthrow of the Islamic Republic. Tehran: Kia.

Ghorbani, M. (2016). Historical deadlock of trust in America. Journal of Political Studies of the day, 15(59), $145-161$.

Griffiths, M. (1999). Fifty key thinkers in international relation. London and New York Rutledge.

HusseiniZadeh, M. A. (2007). Political Islam in Iran. Qom: Mofid University of Humanities.

Izadi, F., \& Mohammadi, M. J. (2011). Production of soft power in the discourse of Islamic Revolution. Journal of Mobilization (Basij) Studies, 14(51), 5-29.

Javedani Moghaddam, M. (2009). The role of Islamic Revolution discourse in international politics. Journal of Islamic Revolution approach, 3(8), 61-88.

Khajuei, M. (2015). Iranian support for the axis of resistance and how to sustain it. Retrieved from http://www.tisri.org/default-2176.aspx

Khezri, E. et al. (2015). The roots of the conflict between Iran and Saudi Arabia (Case Study Iraq, Bahrain and Yemen). Political and International Journal of Islamic Azad University, Shahreza Branch, (23), 179-207.

KhosroShiri, A. (2009). Identity politics. Zamaneh Press, Eighth year. Number 85 and 86. pp. 79 -88.

Laclau, E., \& Mouffe, C. (1985). Hegemony and Socialist Strategy: Towards a Radical Democratic Politics. London: verso.

Me'badi, H., \& Khodaverdi, H. (2006). The great powers and the Islamic Republic of Iran. Tehran: Islamic Revolution Documents Center.

Mostaghimi, B. (2007). The role of culture in formation of foreign policy. In Proceedings of the Conference on Intercultural Communication and Foreign Policy: Iran's approach, Tehran: Al-Hoda International Press.

Motaharnia, M. (2003). An introduction to the Islamic Revolution discourse analysis literature. Tehran: Porseman.

Mousavizadeh, A R., \& Javedani Moghaddam, M. (2008). The role of national culture in foreign policy of the Islamic Republic of Iran. Journal of Political Science, 4(8), 187-226.

Musavi Khomeini, R. (2006). Islam in word and message of Imam Khomeini. Tehran: The Institute for Compilation and Publication of Imam Khomeini's Works.

Musavi Khomeini, R. (2007). Oppression and arrogance from the viewpoint of Imam Khomeini. Tehran: Institute 
for Compilation and Publication of Imam Khomeini's Works.

Niakuyi, A., \& Sotudeh, A. A. (2015). The nature of the Saudi strategy against Iran's Islamic Revolution in Syria and Iraq conflicts. Journal of Islamic Revolution (University of Hamedan), 4(17), 95-110.

Noruzi, M. J. (2010). Logo of the Islamic Republic of Iran. Journal of political knowledge, 2(3), 27-56.

Parsa, R. (2008). Theory of Islamic unity in thought of Shiite clerics emphasizing the votes of Jamaluddin Asadabadi, Ayatollah Boroujerdi, Imam Khomeini, Ayatollah Khamenei and Shahid Motahhari. Master's thesis in political science (the tendency of political thought), Faculty of Islamic Studies and Political Science, University of Imam Sadeq (AS).

Parsai, R., \& Motaharnia, M. (2014). Effectiveness of axis of Iran, Syria and Hezbollah on America's interests in the Middle East. Journal of defense policy, 22(86), 107-138.

Pustinchi, Z. (2010). Soft power in national security discourse of the Islamic Republic of Iran. Journal of Afagh-e Amniyat, 3(7), 7-36.

Rahimnia, M. (2014). Makeup dialogue with militant groups Pahlavi. Journal of Political outcomes.

Ramezani, R. (2007). Analytical framework for the foreign policy of the Islamic Republic of Iran, trans: Alireza Tayyeb, Tehran: Ney Press.

Rezaei Panah, A., \& Nematollahi, N. (2015). Foundations of paradigm shift in the foreign policy of the Islamic Republic of Iran during the Pahlavi era. Quarterly Journal of Islamic Revolution, (15), 119-146.

Ruzi, M. J. (2010). Logo of the Islamic Republic of Iran. Journal of political knowledge, 2(3), 27-56.

Safavi Homami, H. (2008). Dissects the foreign policy of the Islamic Republic of Iran. Tehran: University of Imam Sadeq (AS).

Safavi, S. (1992). Arrogance, America and liberation movements. Tehran: Moalef Press.

Sotudeh, M. (2014). Review the foreign policy of the Islamic Republic of Iran. Qom: Islamic Sciences and Culture Academy.

Taghizadeh Ansari, M. (2000). Political independence and economic independence. Journal of the Faculty of Law and Political Science, (49), 87-118.

Tehrani, H. (2014). The duty of a Muslim in revival of the rule of Islam, arrangement by M Saeidian. Mashhad: Publication of Allameh Tabatabai.

Tooti, H. A., \& Doostmohammadi, A. (2013). Revolutionary developments in Bahrain and Iran's foreign policy and strategies against it. Journal of Islamic Revolution Studies, 10(33), 209-226.

Yar-Mohammadi, L. (2012). Introduction to the discourse. Tehran: Hermes.

\section{Copyrights}

Copyright for this article is retained by the author(s), with first publication rights granted to the journal.

This is an open-access article distributed under the terms and conditions of the Creative Commons Attribution license (http://creativecommons.org/licenses/by/4.0/). 